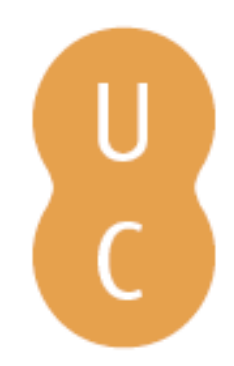

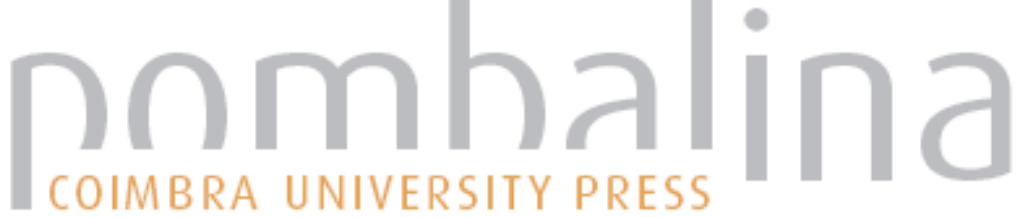

\section{Uma história de Ciência}

Autor(es): $\quad$ Gonçalves-Maia, Raquel

Publicado por: Imprensa da Universidade de Coimbra

URL

persistente: URI:http://hdl.handle.net/10316.2/31301

DOI: $\quad$ DOI:http://dx.doi.org/10.14195/978-989-26-0241-7_2

Accessed : $\quad$ 26-Apr-2023 13:23:54

A navegação consulta e descarregamento dos títulos inseridos nas Bibliotecas Digitais UC Digitalis, UC Pombalina e UC Impactum, pressupõem a aceitação plena e sem reservas dos Termos e Condições de Uso destas Bibliotecas Digitais, disponíveis em https://digitalis.uc.pt/pt-pt/termos.

Conforme exposto nos referidos Termos e Condições de Uso, o descarregamento de títulos de acesso restrito requer uma licença válida de autorização devendo o utilizador aceder ao(s) documento(s) a partir de um endereço de IP da instituição detentora da supramencionada licença.

Ao utilizador é apenas permitido o descarregamento para uso pessoal, pelo que o emprego do(s) título(s) descarregado(s) para outro fim, designadamente comercial, carece de autorização do respetivo autor ou editor da obra.

Na medida em que todas as obras da UC Digitalis se encontram protegidas pelo Código do Direito de Autor e Direitos Conexos e demais legislação aplicável, toda a cópia, parcial ou total, deste documento, nos casos em que é legalmente admitida, deverá conter ou fazer-se acompanhar por este aviso.

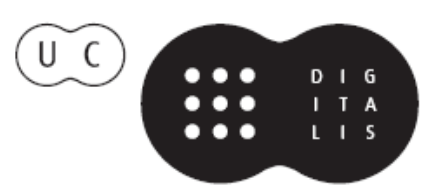




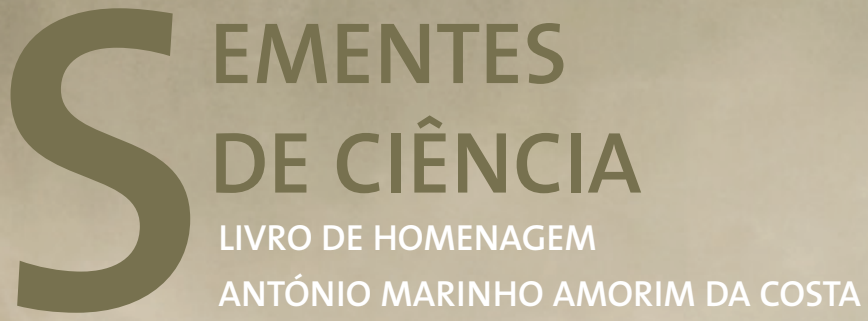

Sebastião J. Formosinho Hugh D. Burrows EDITORES 


\section{II.}

\section{UMA HISTÓRIA DE CIÊNCIA}

Como começar a nossa história? Era uma vez... Estacamos, de imediato. Porque de uma pergunta logo duas e grandes interrogações se levantam: Quando começou a Ciência? Quando começou a História da Ciência? Questões que percorrem os séculos, de diante para trás, e cujas respostas, tal como o espaço e o tempo de um autêntico Big-Bang, terão sofrido uma notável evolução expansionista, desconhecendo-se o início dos inícios e os acontecimentos dos escassos fento-segundos que se seguiram. Mas nós gostamos de datas, de comemorar aniversários. Seja, pois, pelo menos no mundo Ocidental, a Grécia Antiga, lá pelos séculos VII ou vi a.C.

Esta antiquíssima civilização, melhor diríamos civilizações, deu-nos como Primeiro, o Fogo, depois, a Água, o Apeiron e o Ar; por fim, a Terra. E, depois, todos em um, com Empédocles, com Aristóteles. Deu-nos igualmente formas perfeitas, porventura, uma imperfeição, através dos pitagóricos e dos platónicos. E deu-nos os Átomos e o Vazio, filosóficos, dizemos hoje. Ah, encanto nosso, átomos entrando e saindo dos nossos olhos, entrando e saindo do nosso coração... Assim leccionava Demócrito.

Foram muitas as contribuições da Antiguidade Clássica. Eureka!, expressou entusiasmado um siciliano, de seu nome Arquimedes, e repetimo-lo nós. Treze foram os volumes da mais velha Geometria conhecida, a de Euclides, afinal, a que usamos todos os dias. Quem acredita que percorre menor espaço entre dois pontos, se o não cursar em linha recta? 
A Terra, porém, apesar da forte oposição em que Aristarco foi mestre, permanecia no centro - dogma enraizado por Ptolomeu, de cognome "O Maior".

Os romanos foram mais engenheiros que cientistas. Estradas, pontes e aquedutos não tinham segredos nas suas mãos. Bem que Boécio, um clássico, tentou, do grego para o romano, introduzir a "Lógica" de Aristóteles, o "Timeu" de Platão, textos de Galeno, de Hipócrates... mas roubaram-lhe o tempo e a vida.

Eis que então se multiplicaram os árabes pelo Ocidente, atravessado que foi o fino estreito e fácil a invasão da Península Ibérica. Por cá, ficaram sete séculos. E a cultura islâmica reformulou a cultura grega. Ela foi a nossa cartilha. A Medicina, a Matemática, a Astronomia, a Alquimia... muito com eles aprenderam. Decididamente, a Alquimia não é Ciência, a Química é. Mas não se despreze o contributo daquela para esta, o seu legado instrumental, processual, conceptual e mesmo linguístico. Trevas, sim, mas também luz.

O Período Medieval é uma época estranha. Há "bárbaros" que não o são e gregos e romanos que o são em demasia. A Religião ganha um peso material inusitado e temível. O fervor missionário cria escolas e cruzadas, arrasta consigo santos e demónios. Quem o não sabe?

"De Revolutionibus Orbium Coelestium", de Copérnico, foi publicado em 1543. Chave mágica que vai abrir o caminho vitorioso a Galileu Galilei, a Tycho Brahe, a Johannes Kepler e, mais tarde, a Isaac Newton. Sai a Terra do centro, e com ela o Homem, manchas inundam a incorruptibilidade dos astros esféricos, há luas que não são nossas. Heresia? Não. Disse Galileu: "A Biblia retrata o Mundo de Deus", "A Ciência é o livro aberto da Natureza". Nem todos o ouviram.

"De Humani Corporis Fabrica", de Andreas Vesalius, é publicado em 1543. Que coincidência de datas! E aquele decréscimo promissor... 5, 4, 3... Aí está o Renascimento com toda a dinâmica da objectividade necessária à formulação dos conceitos científicos. Com Vesalius, é a revolução anatómica, de profundo impacte biológico. Mas como ele gostaria que Galeno o apoiasse! Outros se lhe irão seguir. A famosa escola médica em Pádua acolhe Fallopio e Fabrizi, muito provavelmente João Rodrigues de Castelo Branco (o nosso mal amado Amato Lusitano, de origem judaica) e, indiscutivelmente, William 
Harvey. O sangue corre impulsionado por um músculo - músculo, o coração, aquele ditoso órgão da afectividade? - em circuito fechado. Recordo mal, ou muito antes já o sábio árabe Ibn Nafis (séc. XIII) o dissera?

O ensino tradicional tende a estagnar nas Universidades. A inovação passa, talvez, pelas Academias, algumas de cariz privado; e igualmente a concepção das primeiras revistas de divulgação da investigação científica de ponta. Tudo começou em Itália, mas, para valer, foi a Grã-Bretanha quem deu as primeiras cartas. A Royal Society, consolidada em 1660, veio para ficar. Entre os seus fundadores, um químico céptico de nome Robert Boyle entreabre a porta à química científica.

Em Portugal, será preciso esperar pela véspera de Natal de 1779, para que a Rainha D. Maria I nos presenteie com a Academia das Ciências de Lisboa.

A Química Pneumática é mote certo por várias décadas. São muitos os Ares de que se fala. Com ou sem espírito, com e sem flogisto, fixos uns, inflamáveis ou incendiários outros, mortos também os há. Gás (ou chaos) é palavra mais indicada, recomenda van Helmont, um pé na Idade Média, outro no Período Moderno. Não rejeitava ele a teoria dos quatro elementos? Não transformava ele mercúrio em ouro?

Depois de Stahl, Cavendish, Black, Scheele, Boyle e Priestley, Lavoisier foi o último dos químicos pneumáticos. Ou o "pai" da Química moderna, não tanto pela abolição do flogisto (não introduziu ele o imponderável calórico?), nem pela sua nova formulação da velha lei da conservação da massa; antes pela metodologia de trabalho, em etapas de objectivo bem esquematizado, com associação do qualitativo ao quantitativo (o uso sistemático da balança), servida por descrições pormenorizadas e imparciais. Lavoisier foi químico amador, homem de leis por formação académica, politicamente um liberal. Dele brotaram reformas sociais, na saúde, na higiene, de hospitais e prisões; reformas do sistema monetário, de impostos, de protecção aos fracos e de combate à fraude fiscal.

A Independência dos Estados Unidos da América e a Revolução Francesa podem parcialmente justificar-se em termos dos direitos humanos. Difícil, porém, é justificar a morte de Lavoisier, vítima do Terror durante a Revolução Francesa. 
O que é um elemento? O que é um composto? O que é um átomo? O que é uma molécula? A Química, que tão cedo começara a acumular conhecimentos, só agora se confrontava com o universo, rico mas caótico, que fora construindo ao longo dos séculos. Lavoisier, primeiro, e o Congresso dos Químicos em Karlsruhe, depois, encontraram as respostas.

A Química profissionaliza-se, sem deixar de ser amadora. Quando o professor Louis Gay-Lussac terminava, com êxito, a análise de um composto particularmente difícil no seu laboratório em Paris, sorria para o seu então discípulo Justus Liebig e dizia-lhe: "Agora, Mr. Liebig, dance comigo, tal como eu costumava dançar com o meu mestre Thenard quando conseguiamos obter alguma coisa boa". E dançavam.

Liebig aprendeu muito em França e foi ensinar na Alemanha, sua terra natal. Fundou a Escola-Laboratório de Giessen, que foi um êxito. A pós-graduação nasceu aqui. O esquecido kaliapparat, um prodígio nas análises químicas ao ponto de ter sido utilizado como logotipo da American Chemical Society, foi obra sua.

A meio da rua da Restauração da cidade do Porto, o Laboratório Médico Prof. Alberto de Aguiar exibe um magnífico friso, e talvez único, de kaliapparat(os) em azulejo criativo. A não perder.

E, logo depois, assiste-se à produção de matéria orgânica a partir de inorgânica. Ureia, sim, "sem um rim, sem um animal, sem um homem ou um cão", escreve Friedrich Wöhler ao seu antigo mestre Jacob Berzelius.

Descende o homem do macaco? As respostas à origem e evolução das espécies, constituem um dos desenvolvimentos mais dramáticos da Ciência. Charles Darwin bem pode descrever a verdadeira tortura mental por que passou: digo ou não digo, escrevo ou não escrevo. Mas quem consegue parar a evolução? Não fizera ele, e outro fizera por ele. "A Origem das Espécies by Means of Natural Selection or the Preservation of Favored Races in the Struggle for Life", cento e cinquenta anos são passados, ainda não consegue ter a aceitação de espíritos empedrenidos.

As ervilheiras de Gregor Mendel deram bons frutos. De pais para filhos, em pelo menos duas gerações. Decididamente, criacionismo não, neo-darwinismo sim. Mas, cuidado! Eugenismo, Racismo, Sociobiologia...? Mas para onde vai o homem? 
No contexto, ainda uma nova questão: É possível gerar vida a partir do nada? O microscópio foi fundamental na observação dos animálculos - eles estão em toda a parte!, mas a princípio alimentou ilusões. O homem provém do homem, o cão do cão, e até os ratos que tanta polémica tinham gerado no passado de ratos nascem. E os tais animálculos, vírus, bactérias, microrganismos que seja, a sua geração é espontânea? Não, afirmou e demonstrou Louis Pasteur.

Alinham-se os elementos pelas suas propriedades, que não pela massa atómica. Espaços ficam por ocupar. Ocupam-se. Assim o fizeram Julius Meyer e Dmitri Mendeleev. Tarefa inglória. Mais elementos vêem a luz, mais e mais elementos, os "gases raros", as "terras raras", onde colocá-los? "Lá chegará o dia" - escreveu Mendeleev - em que se terá uma completa explicação, uma lei primordial da natureza".

Tinha razão. O malogrado Henry Moseley, entre a carga nuclear e a difracção de raios X, concluiu exemplarmente pelo número atómico.

Com uma bomba de vácuo, um tubo de vácuo revela raios. São os raios catódicos e os raios canais, os raios X (tal incógnita padrão da Matemática!) e as radiações alfa, beta e gama. Descobertas do invisível, em ponto grande.

J. J. Thomson tropeça no electrão. Decididamente, o átomo não é uma esfera dura, impenetrável; mas, esconde segredos. Ao electrão, sucede-se o protão e o neutrão. Ernest Rutherford e James Chadwick dão uma boa ajuda. Experiências feitas, passa-se ao modelo. Serve não serve, Niels Bohr quantifica o átomo. Afinal, por que não usufruir da oferta do quantum de Max Planck e do fotão de Albert Einstein?

Mas os físicos não param, dissecam as partículas. Quarks, leptões, bosões, centenas!, até quando?

Uma célula tem os seus cromossomas e o seu papel na hereditariedade. Este foi o caminho iniciado por Mendel, por de Vries. Mas tanto havia ainda a percorrer... e, no entanto, meio século foi suficiente para se desvendar, qual puzzle de muitas peças, a estrutura de dupla hélice do DNA que revela o código genético e determina todos os seres. O ser humano? Nada de muito especial... 
Oswald Avery sabia que a molécula do DNA explicava a função dos genes. Erwin Chargaff sabia que as bases do DNA surgiam, em cada espécie, em proporção idêntica duas a duas. Linus Pauling sabia que certa estrutura das proteínas era helicoidal. Rosalind Franklin e Maurice Wilkins sabiam o que significava a disposição de manchas numa difracção de raios $\mathrm{X}$ do DNA. James Watson e Francis Crick sabiam como recortar cartão, quebrar arame... e interpretar conjugada e correctamente as descobertas dos outros.

Terá o homem uma filiação cósmica? A hipótese da existência de civilizações extraterrestres é quase nula, mas há hipóteses que a Ciência legitima. Outras não. De Panspermia já falavam os gregos, de Radiopanspermia falou o químico Svante Arrhenius e de Panspermia Dirigida Francis Crick. OVNIS? Talvez não. Mas que cometas e meteoritos transportam matéria orgânica sabe-se, hoje, é um facto. E os extremófilos?, eles estão em toda a parte!

O caminho para Estocolmo é, desde 1901, a corrida para a "medalha olímpica" dos cientistas, medalha que ostenta no seu verso, em latim, a famosa frase retirada da "Eneida" de Virgílio: Inventas vitam juvat excoluisse per artes. O polémico Alfred Nobel assim o dispôs, em testamento, para três áreas da Ciência, de fronteira cada vez mais esfumada: Física, Química e Fisiologia ou Medicina. É interessante analisar a influência da atribuição dos prémios Nobel, indubitavelmente os de maior fama e prestígio, no desenvolvimento estrutural da Ciência do século xx.

\section{Da Química para a História}

Tenho de confessar: não fui boa aluna em História nos tempos em que frequentava o liceu. Aquele excelente homem de muito saber, Serras Pereira de seu nome, era pedagogicamente desadequado para ministrar aulas de segundo ciclo a umas boas dezenas de adolescentes em constante mutação celular. E, para mais, o livro de texto era insípido, frio, sem garra para prender cabecinhas tão aéreas. Gostaria eu de História? Que responder!, era pergunta que nem me dava ao trabalho de sugerir a mim própria. 
O tempo passou e a Ciência, pura, dura e exacta, prendeu-me na velha e bonita Escola Politécnica transmutada em Faculdade de Ciências. Uma Química de cá para lá e, estou em crer, de lá para cá. Eis senão que, atingido o quinto ano - então ainda caminho a percorrer para a obtenção da licenciatura -, cruzei-me, obrigatoriamente, com um mestre que dialogava com a História das Ciências, com a História e connosco. Era um tu-cá tu-lá certeiro e disciplinado. Saiu-me a Alquimia na rifa e saí-me eu bem na monografia. Torre de Assunção se chamava o dito mestre e ele foi, sem dúvida, o meu iniciador nesta área do conhecimento.

A tal ponto o tiro fora certeiro que, terminada a Química com bom desempenho e emprego à vista - naquele tempo, por convite -, logo me inscrevi (e não fui sozinha) na Faculdade de Letras, em História, é bom de ver. Foi uma espécie de avidez por Cultura, entendida abrangente e com maiúscula. Algumas disciplinas interessantes, alguns mestres interessantes, mas não passei do primeiro ano. Ah, ser Assistente, descobri-o depressa, era um emprego exigente, ou melhor, um duplo emprego e um só salário. Mas como eu gostava daquilo!, do contacto com os alunos e da investigação. Não havia tempo a perder - e não perdi tempo na elaboração das experiências cruciais, na exploração dos pormenores auspiciosos, nas apresentações orais e em "poster" nos encontros nacionais e internacionais, na aprendizagem da escrita mais ou menos elaborada que compõe qualquer artigo e, finalmente, na descrição de um trabalho árduo em um pouco mais de duzentas folhas que constituiu a minha tese de doutoramento. E as aulas... exigentes, em estudo de conteúdos e na forma eficaz da sua administração.

Acabara-se o espaço para o atendimento próprio de outras aulas, mas não se acabara o espaço para leituras apropriadas. Era uma outra forma de descoberta - assim eu o quisesse - que teria de empreender em intimidade.

Dois novos aspectos não me permitiram o sossego, bem-haja, antes estimularam o desassossego. Comecei bem. "Ciência na História”, obra em vários volumes, escrita por um tal J. D. Bernal, aliás, John Desmond Bernal, o "Sage", o químico de excelência das descobertas estruturais dos compostos orgânicos pela difracção de raios X que, muito provavelmente, nunca recebeu o Prémio Nobel porque era comunista e praticava o amor livre. 
Em Camden Town, no mercado de rua às portas de Londres, exactamente no dia e mês em que eu nasci, um "antique" chamou-me a atenção. "Physics and Philosophy" se chamava o livro, escrito por James Jeans, em edição de 1948. Depressa descobri o gabarito do escritor-cientista e a qualidade da obra. "I need hardly add that my acquaintance with philosophy is simply that of an intruder...", escreve ele no prefácio em forma de "pedir perdão". Por mim, ficou perdoado.

Então, além de se poder correlacionar Ciência e História, era possível coordenar Ciência e Filosofia? Sim. Foram os 20 pence desembolsados mais lucrativos da minha vida.

Esgotaram-se os anos 70 e a nova década colocou-me novas interrogações. E em Portugal? O que se fazia em Portugal - e quem o fazia - neste sentido tão interdisciplinar e culturalmente rico? Não muito. Em grande parte porque, pelo menos a nível universitário, não era bem visto pelos pares que homens de Ciência "gastassem tempo" a desvendar histórias de homens e de acontecimentos do passado, a compreender, a meditar, a interpretar - e muito menos, ainda, do ultrapassado português; perdia-se tempo, e diminuía-se assim o ritmo de publicação de artigos ditos "científicos", ainda que as mais das vezes os tais artigos científicos em nada contribuíssem para o aumento do conhecimento científico. Era uma exigência comandada do exterior, uma quantidade nem sempre aliada à qualidade, em prol de financiamentos indispensáveis.

Não muito, escrevi eu. Havia pouco, de facto, mas havia bom.

Foi nesse tempo que, entre ofertas de boa qualidade, encontrei um "Primórdios da ciência química em Portugal", uma história breve inserida na "Biblioteca Breve", em aposta do Ministério da Educação de 1984. Interessante, concluí após leitura.

\section{A de António e M de Marinho}

Interessante, sem dúvida. E quem era o autor? A. M. Amorim da Costa, um homem distinto em Filosofia e Teologia, licenciado em Química pela 
Universidade de Coimbra, doutorado em Química (Química-Física) pela Universidade de Southampton e Agregado pela Universidade de Coimbra onde era professor. E outras coisas mais. Mesmo muito interessante, conclui em superlativo.

Explorei outras obras de tal autor. O segundo livro seu que li foi a "Introdução à História e Filosofia das Ciências", Colecção Saber "o saber não ocupa lugar", publicado em 1986. Lá estavam sabiamente misturados todos os ingredientes, Mosco, Demócrito e Leucipo dando luz aos átomos da Antiguidade e Thomson, Rutherford e Both aos átomos do século xx, os mestres da tradição oculta medieval e os contemporâneos descarapuçados da transmutação dos elementos, o lógico, o verdadeiro e o plausível, escreve o autor, num contributo epistemológico multifacetado. Gostei. Depois, li "Problemas da Filosofia Química Contemporânea", editado em 1988. Começa assim: Na Natureza nada se repete da mesma maneira; não há dois dias nem dois invernos iguais. Este início espoleta uma análise do evoluir científico, onde a verdade nunca se confunde com a certeza nem põe em causa a objectividade da Ciência. E termina: A Química é uma ciência experimental, em defesa de um empiricismo científico moderno, onde a experiência é o referencial, venha ela a priori ou a posteriori. Gostei.

A curiosidade há muito instalada sobre tal autor levara-me, entretanto, ao seu conhecimento de perto. O Professor Doutor (A. M.) Amorim da Costa, para felicidade minha, metamorfoseou-se de António (M. Amorim da Costa); M de Marinho para que tudo aqui fique claro e desvendado.

Era, nem mais nem menos, do que um conceituado especialista em Espectroscopia de Raman para quem os movimentos rotacionais e vibracionais das moléculas, as suas conformações, orientações e reorientações e as suas ligações inter- e intra- não tinham segredos; ou tinham, e ele, pela sua investigação química aturada, solucionava-os. Propunha modelos e o seu meio de eleição era o estado líquido. Os artigos científicos sucederam-se a bom ritmo ao longo de toda a sua carreira científica. 


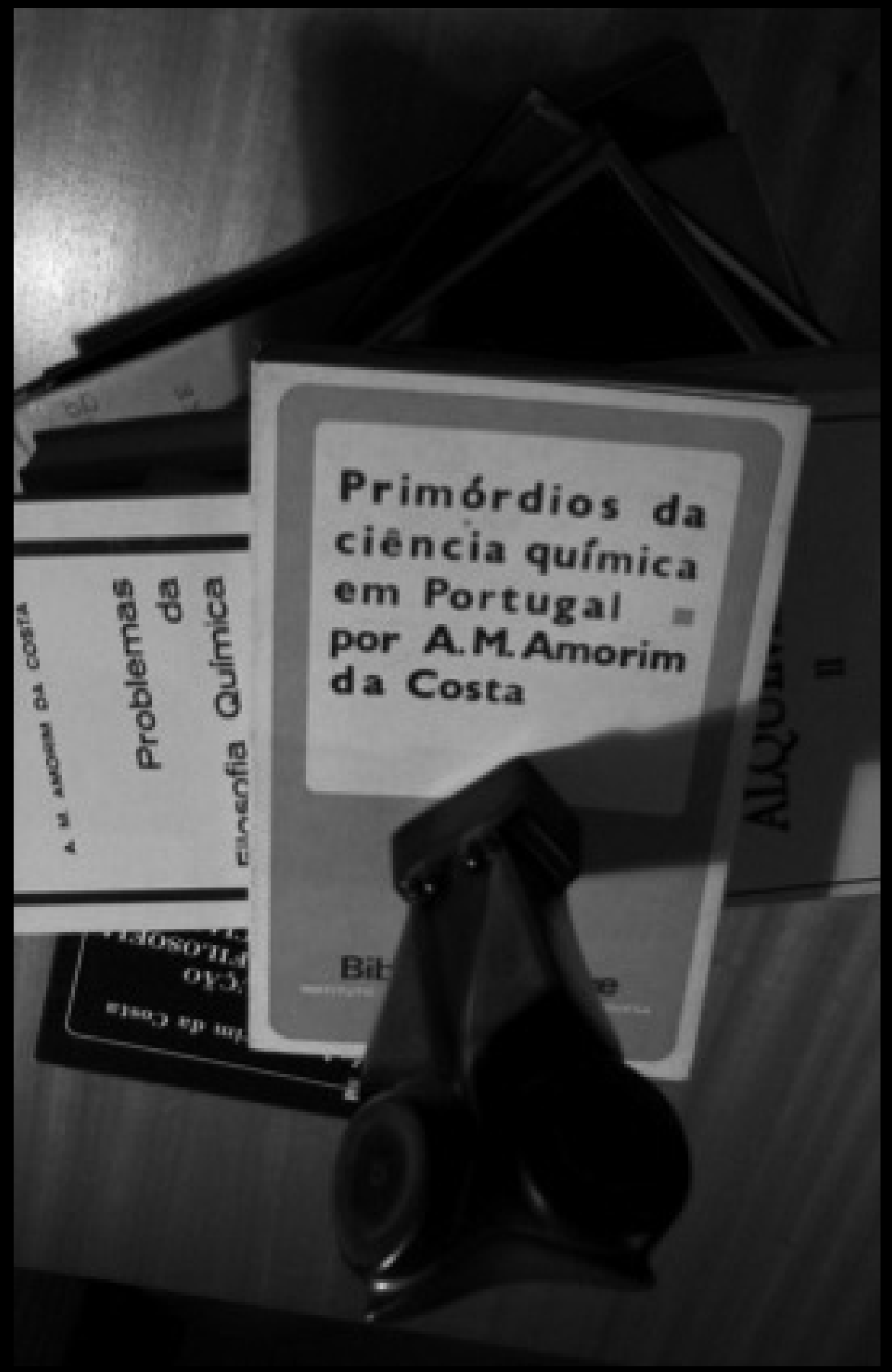


A mente de António Amorim da Costa, porém, era inquieta, que não a postura, essa, recatada e naturalmente recta. A Química é bela, o seu invisível atraente, o seu desconhecido encantador, mas insuficiente para satisfazer um intelecto sedento de harmonia universal; por outras palavras, Amorim da Costa desmutiplicara-se em prol da justificação de uma cultura una, valorizando a História, a Filosofia e o Ensino e Divulgação das Ciências.

É por inaptidão própria que focarei, simplesmente, este lado do espelho.

Se é lícito afirmar que o estado líquido (ou fluído) detinha a sua particular atenção, também estou em crer que Portugal (Coimbra) e os portugueses da Ciência eram o seu tema favorito. Os artigos ou capítulos de livros publicados, só ou em colaboração, "As experiências com "Globos Volantes" realizadas em Coimbra" (1985), "A Iatroquímica Portuguesa" (1985), "A Universidade de Coimbra na Vanguarda da Química do Oxigénio" (1986), "Da Farmácia Galénica à Farmácia Química em Portugal" (1988), "De Stahl a Lavoisier em Portugal Setecentista" (1988), "Chemical Practice and Theory in Portugal in the Eighteenth Century" (1988), "Introduccion de la Química de Lavoisier en Portugal" (1992), "Academismo e Insularidade e o Desenvolvimento da Química em Portugal no século XIX e princípios do século XX" (1996), "Chemistry and the Scientific development of the Country - The XIXth Century in Portugal" (1998), "O Laboratório Chimico da Universidade de Coimbra no século Dezanove" (1998), "Nomenclatura Química Portuguesa no Século XVII" (2003), "O Anti-atomismo dos Conimbricences" (2004), assim como vários outros trabalhos apresentados em colóquios sobre a história do desenvolvimento da Ciência em Portugal são disso exemplo. Em termos um pouco mais específicos, destacamos ainda os seguintes: "Tomé Rodrigues Sobral (1759-1829) - A Química ao serviço da Comunidade" (1986), "Domingos Vandelli (1730-1816) e a cerâmica portuguesa" (1986), "Domingos Vandelli (1730-1816) e a Filosofia Natural na Universidade de Coimbra" (1988), "Da Natureza do Fogo e do Calor na Obra de Vicente de Seabra (1764-1804)" (1991), "Teoria e Experiência nos Elementos de Chimica de Vicente Coelho de Seabra (1764-1804)" (1995), "The Mirror of the Portuguese Chemical Laboratories in the First Decades of the Twentieth Century" (1997), "The Atomic Theory in Simões de Carvalho's "Lessons of Chemical Philosophy"” (2005-comunicação) 
e "Distinguished People and Places Important in the History of Portuguese Analytical Chemistry" (2005).

De entre as figuras emblemáticas das Ciências de genialidade universalmente reconhecida, Amorim da Costa destaca, como se poderia prever, o "pai" da Química moderna e científica: Antoine Lavoisier. Saúda-o, com sincero apreço, mas não the esconde as fragilidades, como se constata pelo inefável "calórico" movimentador das combustões em "O Flogisto na Génese das Teorias de Lavoisier" (1994) ou na impenetrável nomenclatura que ousou propor: "Lavoisier's Chemical Nomenclature in Portugal" (1995).

Por vezes, a Alquimia espiritualizada e/ou racionalizada instalou-se nos seus interesses e o professor, de feição inovadora, explorou-a persistentemente. "Do Mistério e Significado do Cosmos na Tábua de Esmeralda" (1988), "Fogo de Dissolução e Fogo de Combinação" (1990), "Alquimia em Portugal - o Rei Alphonso" (1992), "Etapas do Incógnito: A Procura dos Alquimistas" (1999), "Da Unidade e do Devir Esmeraldinos" (2002) e "No mundo dos Fluidos: o Gás, o Blas e o magnal da Química de J. B. Van-Helmont (1579 - 1644)" (2005) são alguns dos seus artigos emblemáticos desta temática. No livro "Alquimia, Um Discurso Religioso", de 1999, Amorim da Costa expande livre e consistentemente as suas ideias e ideais.

Outras vezes foi a atracção pela História de outras ciências ou a influência de Ciência em Ciência, a Biologia, a Matemática, a Medicina... que motivou a sua análise, como se pode ler, por exemplo, em "A "Estrutura Matemática" da Natureza da Ciência" (1991) ou em "Importação Científica: a Historologia Médica (1733) de José R. de Abreu" (1991).

Ciência, Ensino e Educação, em interacções variadas, expressa-as Amorim da Costa em "O Estado Líquido" (1980), "Do Uso da História da Química no seu Ensino" (1983), "A Constante de Rydberg - Um Século de Refinamento" (1990), "Scientific Instruments and Apparatus" (1990), "Simetria e Quiralidade Moleculares" (1996), "Educação Científica e Educação Literária" (2001), "Chemical Science and Education in the University of Coimbra (Portugal) from 
the Thirties to the Fifties of the Twentieth Century" (2002), "Para que serve a Espectroscopia?" (2003), documentos que se destacam a título exemplificativo. A divulgação científica, reconhecidamente tão útil no despertar de vocações, lê-se com gosto em "Casos de Acaso em Ciência" (1996) ou em "A hipótese dos Quanta, um "Acto de Desespero" (2000).

Da natureza essencialmente epistemológica diferençamos "Temporalização do Espaço versus Especialização do Tempo" (1983), "Química uma Ciência Experimental? Aspectos Históricos do Empirismo Racional" (1987), "Do Simples ao Verosímel em Química. John Dalton e Karl Popper" (1987), "Geocentrismo, Antropocentrismo e Heliocentrismo" (1992), "O Mundo Epistemológico de Ropicapnefma (1532) de João de Barros" (1996), "Da Vida e suas Explicações - Irreversibilidade e Reducionismo" (1998), "Da Vida e suas Explicações Estereoquímica e Vitalismo" (1998) e "A Génese das Substâncias Minerais e o Essencialismo em Ciência" (2002).

Como nós gostamos (ou precisamos...) de catalogar as coisas! Assim fiz, mas fiz mal. Em Amorim da Costa, tema seu subjuga-se sempre a múltiplas observações, são vários os ângulos de estudo que fazem intervir a História, sem dúvida, mas igualmente a opinião da Filosofia, num objectivo concertado de divulgação e educação do leitor. É assim a vida, recheada e entrosada de sabores variados que alimentam o corpo e nutrem o espírito. Como entender de outro modo "Num Universo Aberto e dinâmico" (1991) ou "A Química na Cultura e a Cultura na Química" (1999), artigo este comemorando os 250 anos do nascimento de J. W. Goethe?

\section{Objectivo}

O objectivo deste artigo - ninguém o escreve na ponta final, mas vou atrever-me a fazê-lo - é duplo, como aliás duplo é o sentido da palavra "objectivo".

Em primeiro lugar, ouso fazê-lo na qualidade de remate, uma vez que é do conhecimento geral que, terminada a leitura de uma qualquer obra 
de uma qualquer dimensão, se retorna ao início a fim de se verificar se "foram cumpridos os objectivos". Poupo-vos, pois, esse trabalho.

Em segundo lugar, e antes de prosseguirmos, debrucemo-nos por uns instantes no citado duplo sentido de "objectivo": como substantivo, entende-se como "matéria, questão ou tema", "fim, propósito ou alvo"; como adjectivo é, porventura, ainda mais interessante, "assente em observação imparcial".

Na fusão redentora, multi e interdisciplinar, que temos tentado introduzir ao longo deste artigo, amalgamámos deliberada e justificadamente as Ciências (preponderância seja reconhecida para a Química) com a História e a Filosofia das Ciências e o contributo inegável e convincente de António Amorim da Costa.

O que conhecemos? (O que não conhecemos...), como conhecemos? Toda a Ciência se constrói numa sucessão de passos, alguns reconhecidos de gigantes no imediato, outros, só décadas passadas, ganham subitamente a dimensão de descoberta. Não fosse o contributo da História para nos recordar o esquecido... não fosse a nossa própria reflexão ponderada alicerçada em muitas leituras de muitos pensadores... e a justeza e as fronteiras da investigação de cada um perder-se-iam. A sugestão, a priori, e a crítica, a posteriori, venham elas de onde vierem, são indispensáveis ao saudável discernimento. Quem seria Lavoisier se Stahl não tivesse existido? Que terá dito Einstein a Newton se, porventura, se encontraram?

A inteligibilidade - dos fundamentos, dos argumentos e das explicações - são dados fundamentais do discurso científico escorreito. A mensagem assim transmitida é muito mais do que um simples aglomerado de dados observados ou de equações matemáticas encadeadas. Mas, para isso, a Ciência necessita de ter presente que, como bem dizia o nosso multifacetado Joseph Priestley, "para facilitar o avanço de qualquer ramo da Ciência [...] é requerido o conhecimento histórico do seu surgimento, progresso e estado actual; depois, um canal aberto de comunicação de novas descobertas".

Muitos contribuíram, e um e outro em particular, para retirar o homem das trevas, a Terra do centro do Universo, o Sistema Solar do centro da Via Láctea, o homem do seu revestimento de eleição; para desenrolar o novelo dos princípios, primitivos e corpúsculos, dos elementos e dos corpos simples, dos compostos, mistos e sobrecompostos, dos átomos e das moléculas, das 
suas ligações, conformações, orientações e reorientações. Temos o dever de conhecê-los.

Homenagem justa aqui se faz a um homem em particular, cientista, historiador da Ciência com laivos de filósofo e de sociólogo que muito nos tem dado a conhecer; da Química e da pré-Química, em particular.

Amorim da Costa investigou e historiou a Ciência, analisou linhas do seu desenvolvimento, incluiu-a num contexto profundamente humano, social e cultural. Não se espere milagres porque o poço é profundo e recheado. Mas muito se deve ao cientista-historiador. A obra de Amorim da Costa tanto o aprova como professor e investigador em Química, como, se não mais, o consagra como professor e historiador da Ciência.

\section{Bibliografia}

Amorim da Costa, A.M., "Primórdios da ciência química em Portugal", Biblioteca Breve, ICLP ME, Lisboa, 1984.

Amorim da Costa, A., "Introdução à História e Filosofia das Ciências", Publicações Europa-América, Colecção Saber, Mem Martins, 1986.

Amorim da Costa, A.M., "Problemas da Filosofia Química Contemporânea", Coimbra Editora, Coimbra, 1988.

Bernal, J.D. "Ciência na História”, Vol. I a VI, Colecção Movimento, Livros Horizonte, Lisboa,

Gonçalves-Maia, R., "O Legado de Prometeu - Uma Viagem na História das Ciências”, Escolar Editora, Lisboa, 2006.

Gonçalves-Maia, R., "O Legado de Nobel - Perfis na Ciência do Século XX (1900-1959)", Escolar Editora, Lisboa, 2008.

Gribbin, J., “Science - A History 1543-2001”, Penguin Books, Londres, 2002.

Hargitai, I., "The Road to Stockholm - Nobel Prizes, Science, and Scientists", Oxford University Press, Oxford, 2002.

Maia, H. E Dias, I., "Origem da Vida - Recentes Contribuições para um Modelo Científico", Escolar Editora, Lisboa, 2008.

Jeans, J., "Physics \& Philosophy", University Press, Cambridge, 1948.

Pacheco, F.C., "Um Século de Medicina Laboratorial. O Laboratório Médico Prof. Alberto de Aguiar", Ordem dos Médicos (Conselho Regional do Norte), Porto, 1998. 